\title{
Teknik Literasi Silang Dalam Model Problem Based Learning: Alternatif Pembelajaran di Masa Pandemi Covid19
}

\author{
Cholifah Tur Rosidah \\ Universitas PGRI Adi Buana Surabaya
}

Corresponding author email: cholifah@unipasby.ac.id

Keyword:

Cross literacy,

Problem based

learning, Online

Learning, Covid-19

Pandemic

\section{Abstract:}

The Covid-19 pandemic has an impact on all lines of life, one of which is the education aspect. The government's policy to implement online lectures has made the lecture process, which was originally face-to-face, also blended learning turned into a full online lecture. This is the basis for researchers to find alternative learning techniques that can be applied in the full online lecture process. In addition, it is also to describe the level of activeness of students in lecturing activities. This study uses a qualitative approach to describe the application of cross-literacy techniques in the problem-based learning model and the students' responses to the implementation of cross-literacy techniques in the problem-based learning model in Indonesian language learning subjects. The research was conducted at the PGSD Study Program at Adi Buana University. Precisely for the 4th semester students taking Indonesian language learning courses in class A. The data was collected using a non-test technique using a list of interview questions, questionnaires and observation sheets. The response to the implementation of the application of the cross literacy technique in the problem-based learning model showed that $89 \%$ of students felt that the application of the technique was interesting, made lectures less boring and it became easier to understand the material. Strongly agree with the application of cross literacy techniques in the problem based learning model. The remaining $11 \%$ responded in agreement with the application of the technique. 


\section{Pendahuluan}

Tahun 2020 dunia sedang mengalami bencana besar berupa pandemi virus corona yang popular dengan nama Covid-19. Virus tersebut dengan cepat menyebar ke berbagai negara di seluruh dunia. Pandu Riono pakar Epidemiologi Universitas Indonesia menjelaskan dalam diskusi yang dilakukan secara daring dalam tajuk Mobilitas Penduduk dan Covid-19 tersebut bahwa virus jenis SARS-Cov-2 atau yang lebih popular sebagai corona telah ada di Indonesia sejak awal Januari, meski pemerintah kali pertama mengumumkan adanya kasus pasien positif covid-19 pada tanggal 2 Maret 2020 (BREAKING NEWS: Jokowi Umumkan Dua Orang di Indonesia Positif Corona Halaman all - Kompas.com, no date).

Sejak saat itu laporan kumulatif konfirmasi positif covid-19 yang diumumkan pemerintah melalui media massa selalu menunjukkan data grafik yang semakin meningkat. Penyebarannya yang masif dan relatif cepat menimbulkan kegelisahan di masyarakat. Semua warga terpaksa harus diam di rumah untuk menghentikan penularan Covid-19. Hampir semua agenda yang melibatkan banyak massa dibatalkan bahkan dihilangkan. Dampaknya telah menyentuh semua lini kehidupan. Tak terkecuali sektor pendidikan.

Menanggapi hal tersebut, pemerintah dengan sigap mengeluarkan beberapa kebijakan yang berkaitan dengan pendidikan

di masa darurat covid-19 diantaranya 1) Pembelajaran daring siswa sekolah; 2) Kuliah daring untuk mahasiswa; 3) Ditiadakan Ujian Nasional 2020; 4) Pengunduran jadwal UTBK SBMPTN 2020; dan 5) Pengkajian ulang pelaksanaan SNMPTN (Sevima, 2020). Berdasar pada Surat Edaran Mendikbud Nomor 3 Tahun 2020 tentang Pencegahan COVID-19 pada Satuan Pendidikan, dan Nomor 36962/MPK.A/HK/2020, kegiatan belajar mengajar dilakukan secara daring untuk mencegah perluasan Covid-19.

Perubahan pola pembelajaran dari pembelajaran tatap muka menjadi pembelajaran daring memaksa pengajar belajar dengan cepat. Berbagai metode pembelajaran dilakukan untuk memenuhi kebutuhan pembelajaran daring. Hal tersebut dilakukan agar kompetensi abad 21 yang menjadi tuntutan penguasaan peserta didik tetap dapat dicapai secara optimal dalam berbagai nuansa belajar.

Abad 21 merupakan suatu masa yang identik dengan penggunaan dan pemanfaatan teknologi informasi. Dengan berbagai tantangan kehidupan yang terjadi, pendidikan pun harus mampu bersifat dinamis sehingga dapat mengimbangi perubahan-perubahan yang terjadi dengan berbagai perkembangan ilmu pengetahuan yang dapat menjadi bekal bagi peserta didik dalam menjalani kehidupannya. Dengan demikian muncullah pembelajaran abad 21 pada masa yang disebut 
juga dengan masa pengetahuan (knowledge age) saat ini.

Pembelajaran abad 21 dirancang dengan mengintegrasikan berbagai keterampilan dan visi pembelajaran ke dalam proses belajar yang tergambar pada kerangka Framework for $21^{\text {st }}$ Century Learning. Kerangka tersebut menggambarkan pengetahuan, keterampilan, dan keahlian yang bermanfaat bagi kehidupan peserta didik. Penerapan setiap keterampilan abad 21 membutuhkan pengembangan pengetahuan dan pemahaman subjek akademik, dengan harapan peserta didik mampu berpikir kritis, berkomunikasi secara efektif, memecahkan masalah, dan juga berkolaborasi dengan orang lain untuk membangun kerjasama.

Salah satu cara agar dapat mencapai pengembangan pengetahuan secara optimal, guru dapat mengaplikasikan model pembelajaran yang sesuai agar proses pembelajaran menjadi lebih bermakna. Pendekatan pembelajaran berbasis masalah memiliki sejarah panjang dalam menganjurkan pendidikan berbasis pengalaman. Penelitian dan teori psikologi menunjukkan bahwa dengan meminta peserta didik belajar melalui pengalaman memecahkan masalah, mereka dapat mempelajari konten dan strategi berpikir. Pembelajaran berbasis masalah adalah model pembelajaran yang mengajarkan peserta didik untuk belajar melalui pemecahan masalah yang difasilitasi (Thomas, 2009). Dalam Problem Based Learning (PBL), pembelajaran peserta didik berpusat pada masalah kompleks yang tidak memiliki satu jawaban benar. Peserta didik bekerja dalam kelompok kolaboratif untuk mengidentifikasi materi-materi yang perlu dipelajari untuk memecahkan masalah. Peserta didik terlibat dalam pembelajaran mandiri (Self Directed Learning), kemudian menerapkan pengetahuan baru mereka pada masalah dan merefleksikan materi-materi yang telah dipelajari dan efektivitas strategi yang digunakan. Pengajar bertindak memfasilitasi proses pembelajaran (Barratt-Pugh, 2020).

\section{Tujuan Problem Based Learning} diantaranya untuk mengembangkan 1) pengetahuan yang fleksibel, 2) keterampilan pemecahan masalah yang efektif, 3) keterampilan SDL, 4) keterampilan kolaborasi yang efektif, dan 5) motivasi intrinsik. Artikel ini membahas sifat pembelajaran di PBL dan memeriksa bukti empiris yang mendukungnya (Hmelo-Silver, 2004). Ada banyak penelitian tentang 3 tujuan pertama PBL tetapi sedikit pada 2 tujuan terakhir. Memahami cara pencapaian tujuan oleh peserta didik yang kurang terampil merupakan bagian penting dari agenda penelitian PBL. Bukti menunjukkan bahwa PBL ialah pendekatan instruksional yang menawarkan potensi untuk membantu peserta didik mengembangkan pemahaman yang fleksibel dan keterampilan belajar seumur hidup (Savery, 2015).

Agar optimalisasi potensi yang menjadi tujuan model PBL dapat dicapai, maka harus 
didukung dengan kemampuan literasi peserta didik. Literasi merupakan proses memperoleh pengetahuan terhadap perilaku dan keahlian dalam bidang informasi, sebagai penentu utama dari cara manusia mengeksploitasi kenyataan, membangun hidup, bekerja, dan berkomunikasi dalam komunitas informasi (Lien et al., 2020). Proses pembelajaran yang menanamkan kebiasaan literasi ialah pembelajaran yang dirancang agar peserta didik mengerti, menyadari, memahami, dan menggunakan tulisan (bacaan dan sumber informasi). Dengan kata lain, selain mempunyai budaya lisan/tutur mengembangkan budaya baca dan tulis (Setiawan, 2020). Berdasarkan definisi tersebut dapat dikatakan bahwa literasi merupakan kemampuan seseorang untuk mengenali informasi yang dibutuhkan, menemukan letak informasi, kemudian mengevaluasi dan juga mampu menggunakan informasi secara efektif. Untuk memperkaya referensi peserta didik, salah satunya dapat diterapkan melalui teknik literasi silang.

Teknik literasi silang merupakan teknik pembelajaran dengan saling bertukar informasi yang didapat (Subandiyah, 2017). Melalui teknik literasi silang, peserta didik memiliki kesempatan lebih luas dalam memperdalam materi ajar dengan menemukan konsep, fakta, daan penyelesaian atas permasalahan dari materi ajar. Hal ini sejalan dengan filosofi pada model pembelajaran PBL. Berdasarkan pemaparan latarbelakang tersebut, penelitian ini bertujuan untuk mendeskripsikan pelaksanaan teknik pembelajaran yang dapat diterapkan dalam proses perkuliahan daring penuh melalui penerapan teknik literasi silang dalam model PBL. Selain itu juga untuk memaparkan respon mahasiswa terhadap penerapan teknik literasi silang dalam model PBL.

\section{Metode}

Penelitian dilaksanakan di Program Studi PGSD Universitas PGRI Adi Buana Surabaya pada mahasiswa semester 4 yang menempuh Mata Kuliah Pembelajaran Bahasa Indonesia tahun ajaran 2019/2020 di kelas 2018A. Penelitian menggunakan pendekatan kualitatif deskriptif. Teknik pengumpulan data dilakukan dengan cara observasi, penyebaran angket, dan wawancara. Pengujian keabsahan data dilakukan dengan triangulasi teknik.

Tahapan pelaksanaan penelitian didahului dengan studi lapangan dan studi literatur, hingga ditemukan permasalahan. Selanjutnya ditentukan subjek penelitian. Menyusun instrumen yang dibutuhkan dalam pengambilan data, memvalidasi pada validator ahli sesuai dengan topik penelitian, dan merevisi. Setelah semua isntrumen siap, pelaksanaan penelitian dilakukan secara daring melalui google meet. Dalam proses tersebut dilakukan observasi terkait dengan proses pelaksanaan penerapan teknik literasi silang dalam model pembelajaran problem based learning menggunakan lembar observasi. Setelah proses perkuliahan selesai, peneliti 
menyebarkan angket yang dibuat dalam google form untuk mendapatkan data respon mahasiswa terhadap pelaksanaan penerapan teknik literasi silang dalam model pembelajaran problem based learning. Selanjutnya informasi mendalam didapat dengan melakukan wawancara pada 3 mahasiswa yang diambil secara random. Data yang didapat selanjutnya dianalisis untuk mengetahui hasil penelitian. Adapun tahapan tersebut dapat dilihat pada gambar 1 berikut ini.

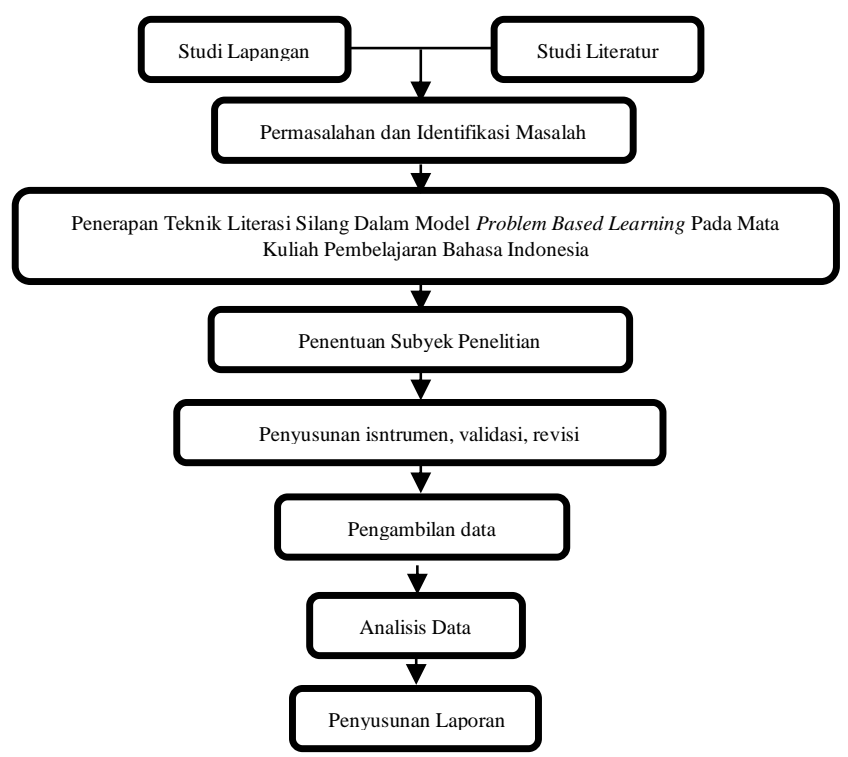

Gambar 1. Tahapan pelaksanaan penelitian

\section{Hasil dan Pembahasan}

Setelah pandemi Covid-19 masuk ke Indonesia yang selanjutnya pada pertengahan Maret 2020 pemerintah provinsi dan daerah menghasilkan kebijakan dalam dunia pendidikan yaitu meniadakan sementara pembelajaran tatap muka diganti dengan pembelajaran online baik tingkat sekolah maupun perguruan tinggi untuk menekan angka penderita Covid 19, diwujudkan suatu sistem yang disebut electronic university (eUniversity). Pengembangan e-University bertujuan untuk mendukung penyelenggaraan pendidikan, sehingga dapat menyediakan layanan informasi yang lebih baik kepada komunitasnya, baik di dalam maupun di luar perguruan tinggi tersebut melalui internet (Ferdig et al., 2020). Layanan pendidikan lain yang bisa dilaksanakan melalui sarana internet yaitu dengan menyediakan materi kuliah secara online dan materi kuliah tersebut dapat diakses oleh siapa pun yang membutuhkan.

Pandemi covid-19 memaksa sistem pembelajaran harus moderat dengan teknologi yang memungkinkan peserta didik belajar lebih cepat, lebih baik, dan lebih pintar (Basilaia and Kvavadze, 2020). Teknologi Informasi adalah kunci untuk model pembelajaran masa depan yang lebih baik. Dengan demikian diterapkan teknik literasi silang dalam model Problem based learning sebagai salah satu alternatif pembelajaran. Adapun hasilnya sebagai berikut.

\section{Penerapan teknik literasi silang dalam model Problem based learning}

Penerapan Teknik literasi silang dalam model PBL yaitu dengan mengintegrasikan langkah-langkah pembelajaran model berbasis masalah dan teknik literasi silang. Teknik literasi silang dilakukan pada tiap tahapan model PBL. Adapun penerapannya dapat 
dilihat pada masing-masing prosedur berikut ini.

Merumuskan Masalah terdiri dari 5 prosedur yaitu (1) menganalisis kemungkinan materi/konsep yang memungkinkan dijadikan masalah (masalah harus kontekstual dan konkrit sesuai kehidupan peserta didik); (2) menentukan fokus masalah; (3) mencari subsub masalah; (4) mengkaji sub-sub masalah yang paling menarik dan paling penting untuk ditelaah; (5) Pilih dan tetapkan masalah. Pada tahap merumuskan masalah, teknik literasi silang diterapkan pada prosedur mengkaji subsub masalah.

Menganalisis Masalah, terdiri dari 4 prosedur diantaranya (1) Understand, memahami masalah yang diberikan; (2) Identify, mengidentifikasi kebutuhan penyelesaian masalah (konsep dan fakta yang terkait masalah); (3) Analyze, menganalisis variabel pengaruh dan variabel terikat terkait masalah; (4) Report, membuat uraian singkat/sederhana keterkaitan antar variabel masalah. Pada tahap menganalisis masalah, teknik literasi silang dilakukan pada prosedur identifikasi dan analisis.

Merumuskan Hipotesis, terdiri atas prosedur (1) Buat hipotesis preliminer atau pendahuluan; (2) Kumpulkan fakta terkait masalah (hal-hal yang perlu dibuktikan, kebutuhan data, sumber data); (3) Formulasi hipotesis; (4) Pengujian hipotesis; dan (5) Rumuskan hipotesis. Pada tahap merumuskan hipotesis, teknik literasi silang dilakukan pada prosedur mengumpulkan fakta terkait masalah.

Mengumpulkan Data, terdiri atas prosedur (1) Menyusun instrumen maupun pertanyaan-pertanyaan yang diarahkan pada kegiatan pengumpulan data; (2) Menentukan lokasi dan waktu pengumpulan data; (3) Menentukan informan-informan sebagai narasumber; (4) Mendapatkan ijin pengambilan data; (5) Memutuskan tipe-tipe data yang dikumpulkan; (5) Pencatatan data yang diperlukan. Pada tahap mengumpulkan data, teknik literasi silang dilakukan pada semua prosedur.

\section{Merumuskan}

Rekomendasi

Pemecahan Masalah, terdiri atas prosedur (1) Tulis berbagai alternatif pemecahan masalah berdasarkan pada data yang telah didapat; (2) Analisis masing-masing alternatif atau rekomendasi pemecahan masalah;

Tentukan dan pilih salah satu rekomendasi pemecahan masalah yang lebih banyak kelebihan daripada kekurangannya. Pada tahap merumuskan rekomendasi pemecahan masalah, teknik literasi silang dilakukan pada prosedur analisis alternatif pemecahan masalah.

\section{Penyusunan Laporan dan Presentasi}

Hasil, terdiri atas prosedur (1) Tulis kegiatankegiatan yang telah dilakukan dalam proses pemecahan masalah; (2) Tulis hasil pengumpulan data berdasarkan fakta yang di dapat; (3) Tulis simpulan, solusi dan saran atas permasalahan yang telah dipecahkan. 
Pada masing-masing Langkah pembelajaran tersebut, mahasiswa diberi kesempatan untuk saling bertukar informasi. Mencari informasi baik dengan teman dalam satu kelompok maupun teman dari kelompok lain. Adapun penerapannya dapat dilihat pada bagan gambar 2 berikut ini.

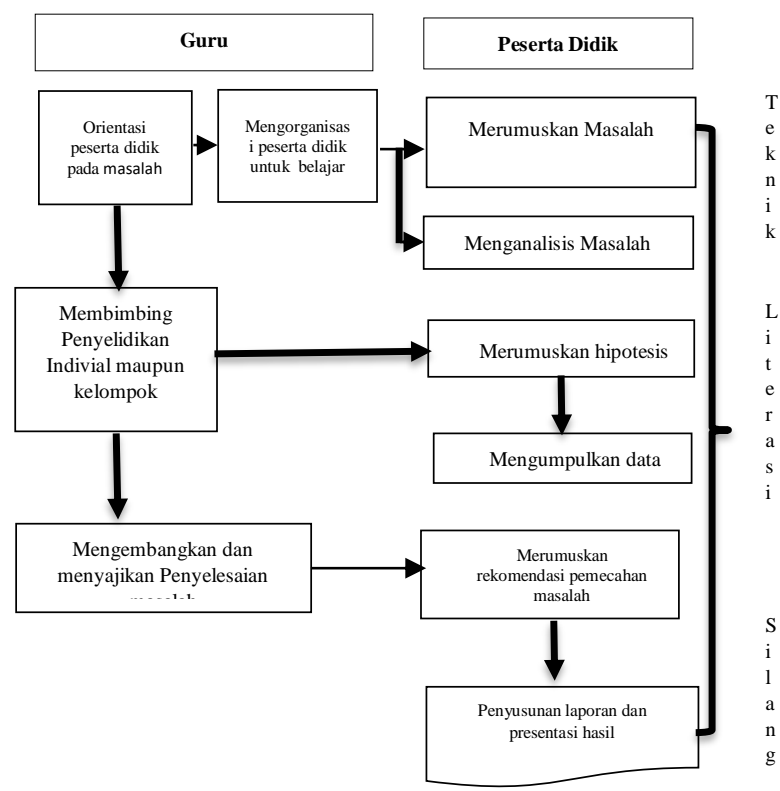

Gambar 2. Prosedur Pelaksanaan

Teknik Literasi Silang dalam Model Problem

\section{Based Learning}

Hasil penerapan teknik literasi silang dalam model problem based learning didapat dari observasi pelaksaanaan pembelajaran. Proses perkuliahan di masa pandemi covid-19 dilakukan secara daring penuh. Salah satu Learning Managemant System (LMS) yang digunakan di Universitas PGRI Adi Buana Surabaya yaitu Virtual Learning environtment of Adi Buana atau biasa disebut Virlenda.

Pada tahap awal, merumuskan masalah dosen memandu prosesnya melalui web meeting dengan menggunakan fitur
Bigbluebotton yang ada dalam Virlenda. Melalui web meeting tersebut, dosen dapat mengamati pelaksanaan pembelajaran melalui proses brainstorming untuk mengkaji sub-sub masalah yang diberikan oleh dosen. Dalam proses tersebut diterapkan teknik liteasi silang dengan cara mahasiswa menyampaikan pendapat sesuai dengan pengetahuan dan penglaman belajar yang dimiliki sebelumnya dengan mengaitkan pada topik permasalahan yang diberikan oleh dosen, yaitu problematika pembelajaran Bahasa Indonesia di SD. Mahasiswa saling bertukar informasi secara klasikal, sehingga informasi bisa didapat dari semua teman, baik sekelompok maupun diluarnya. Hingga dapat memilih dan menetapkan masalah yang akan dipecahkan.

Selanjutnya pada langkah menganalisis masalah dan merumuskan hipotesis, mahasiswa dibimbing untuk melakukan diskusi dengan kelompoknya melalui forum yang dibuat perkelompok. Dalam forum tersebut, dosen dapat memantau pemahaman mahasiswa terhadap masalah yang diberikan, ketepatan identifikasi kebutuhan-kebutuhan hasil penyelesaian masalah, ketapatan hasil analisis variabel pengaruh dan variabel terikat terkait masalah, serta uraian singkat keterkaitan antar variabel masalah. Hingga hipotesis dapat dirumuskan dengan tepat. Selain itu dosen juga dapat mengarahkan agar diskusi atau proses penerapan teknik literasi silang tetap terlaksana dengan baik. 
Pada langkah pengumpulan data mahasiswa diberi kesempatan untuk saling bertukar informasi dan pendapat untuk membantu pemecahan masalah. Proses saling informasi bisa dilakukan sesama anggota kelompok maupun antar anggota kelompok. Berdasarkan proses tersebut, mahasiswa dapat merekomedasi penyelesaian masalah yang diberikan oleh dosen. Langkah terakhir setiap kelompok mempresesntasikan hasil yang di dapat. Sedangkan, kelompok lain disilakan untuk memberikan pendapatnya berupa saran maupun komentar.

Respon Mahassiswa Terhadap Penerapan teknik literasi silang dalam model Problem

\section{based learning}

Pelaksanaan proses pekuliahan secara daring dengan menerapkan teknik literasi silang dalam model problem based learning tidak mengurangi antusias mahasiswa dlam mengikuti setiap proses yang dilaksanakan. Proses pencarian informasi dengan teknik literasi silang terhadap sesama anggota kelompok, maupun teman diluar kelompok dapat dilakukan dengan menggunakan fitur chat atau obrolan. Selain itu karena proses perkuliahan daring penuh, mahasiswa juga dengan mudah untuk mencari informasi di mesin pencarian sebagai pendukung informasi-informasi yang diperlukan untuk pemecahan masalah.

Respon mahasiswa didapat melalui hasil penyebaran angket yang dilakukan melalui pengisian google form. Angket tersebut berisi pernyataan yang bersifat positif dan negatif. Adapun hasil yang didapat yaitu $82 \%$ mahasiswa termotivasi untuk mengikuti proses perkuliahan. $87 \%$ menilai penerrapan teknik terseebut sangat menarik dan tidak membosankan. $85 \%$ lebih mudah memahami materi. $89 \%$ lebih mudah menyelesaikan permasalahan yang diberikan oleh dosen dengan menerapkan teknik literasi silang. 93\% mahsiswa merasa lebih dihargai dalam mengelurkan pendapat. $95 \%$ merasa bahwa penerapan teknik literasi silang dalam model PBL dapat membangun hubungan yang lebih baik antar sesama teman. 88\% mampu menghubungkan materi perkuliahan dengan kondisi masyarakat kekinian.

\section{Kesimpulan}

Penerapan teknik literasi silang dalam model PBL mendapatkan respon possitif dari mahasiswa sebagai subjek belajar. Teknik tersebut dapat membuat mahasiswa lebih termotivasi dan tertantang untuk menyelesaikan permasalahan yang diberikan. Selain itu juga dapat memberikan dampak positif dalam kehidupan sosial diantaranya mereka merasa pendapatnya lebih dihargai dan dapat membangun hubungan yang lebih baik dengan teman. Selain itu juga lebih mudah memahami materi dan mampu menghubungkan materi perkuliahan dengan kondisi masyarakat kekinian.

Penerapan teknik literasi silang dapat digunakan pada semua mata kuliah yang 
memungkinkan mahasiswa mencari informasi

seluas-luasnya.

\section{Daftar Pustaka}

Barratt-Pugh, C. (2020) 'The socio-cultural context of literacy learning', in Literacy learning in the early years. Routledge, pp. $1-26$.

Basilaia, G. and Kvavadze, D. (2020) 'Transition to online education in schools during a SARS-CoV-2 coronavirus (COVID-19) pandemic in Georgia', Pedagogical Research, 5(4), pp. 1-9.

BREAKING NEWS: Jokowi Umumkan Dua Orang di Indonesia Positif Corona Halaman all - Kompas.com (no date). Available at: https://nasional.kompas.com/read/2020/03/ 02/11265921/breaking-news-jokowiumumkan-dua-orang-di-indonesia-positifcorona?page $=$ all (Accessed: 3 September 2020).

Ferdig, R. E. et al. (2020) 'Teaching, technology, and teacher education during the covid-19 pandemic: Stories from the field', Waynesville, NC, USA: Association for the Advancement of Computing in Education (AACE).
Hmelo-Silver, C. E. (2004) 'Problem-based learning: What and how do students learn?', Educational Psychology Review. Springer, pp. 235-266. doi: 10.1023/B:EDPR.0000034022.16470.f3.

Lien, D. A. et al. (2020) Literasi informasi: 7 langkah knowledge management. Penerbit Universitas Katolik Indonesia Atma Jaya.

Savery, J. R. (2015) 'Overview of problembased learning: Definitions and distinctions', Essential readings in problem-based learning: Exploring and extending the legacy of Howard S. Barrows, 9, pp. 5-15.

Setiawan, A. R. (2020) 'Pembelajaran Tematik Berorientasi Literasi Saintifik', Jurnal Basicedu, 4(1), pp. 51-69.

Subandiyah, H. (2017) 'Pembelajaran literasi dalam mata pelajaran bahasa indonesia', Paramasastra, 2(1).

Thomas, I. (2009) 'Critical thinking, transformative learning, sustainable education, and problem-based learning in universities', Journal of Transformative Education, 7(3), pp. 245-264. 